\title{
Nutritional analysis of some selected medicinal plants of Khyber Pakhtunkhwa, Pakistan
}

Hussan Ara Begum ${ }^{1 *}$, Muhammad Hamayun ${ }^{1}$, Noor Shad ${ }^{2}$, TabassumYaseen ${ }^{3}$ and Fayaz Asad ${ }^{3}$

1. Department of Botany, Abdul Wali Khan University Mardan, KP-Pakistan

2. Department of Biochemistry, Abdul Wali Khan University Mardan, KP-Pakistan

3. Department of Botany, Bacha Khan University Charsadda, KP-Pakistan

*Corresponding author's email: hussanara.begum@gmail.com

Citation

Hussan Ara Begum, Muhammad Hamayun, Noor Shad, TabassumYaseen and Fayaz Asad. Nutritional analysis of some selected medicinal plants of Khyber Pakhtunkhwa, Pakistan. Pure and Applied Biology. Vol. 7, Issue 3, pp955-964. http://dx.doi.org/10.19045/bspab.2018.700114

\begin{tabular}{llll}
\hline \hline Received: 21/04/2018 & Revised: 10/07/2018 & Accepted: 13/07/2018 & Online First: 16/07/2018
\end{tabular}

\section{Abstract}

Plant biodiversity contribute significantly to human health, nourishing and nurturing them and alleviating their acute and chronic diseases. Plants not only served as curing agents since long but also providing basic nutrients like carbohydrates, protein, fat etc. These nutrients have essential role in supporting human body requirements for vigor, used in different physiological and morphological functions. In present study, Cucumis sativus, Portulaca oleracea, Malus baccata, Saxifraga flagillaris, Geranium wallichianum and Monotheca buxifolia, were assessed for their nutritional and proximate composition (ash, moisture, protein, carbohydrates and fat) subjected to Association of Official Analytical Chemist (AOAC) procedure based to their ethno botanical importance. In results, the comparative assessment of these selected plants showed that Carbohydrates was highest in Monotheca buxifolia (74.27\%), followed by Geranium wallichianum (64.68\%) and Saxifraga flagillaris (62.79\%). Ash content was highest in Portulaca oleracea (26.44\%), followed by Malus baccata (22.83\%) and Cucumis sativus (20\%). Malus baccata possessed highest percentage of moisture (18.69\%). Saxifraga flagillaris has highest percentage of protein (4.37\%). Cucumis sativus consisted of highest percentage of fat (14\%). It is concluded from the present study that medicinal plants play crucial role in human life and are praiseworthy springs of food nutrients and therapeutics associate in human health.

Keywords: Carbohydrates; Fat content; Medicinal plants; Nutritional analysis; Protein content

\section{Introduction}

From dawn of civilization human depend mostly on plants for nutrition and also for the extenuation of illnesses. Natural plants harvests continuously subsidized broadly to the isolation of contemporary medicine and still possess a noteworthy part in finding of newer medication. Human use an extensive variety of plant derivative as food, drug and nutritional increments [1]. Plants providing rudimentary healthcare to the fringe people of the biosphere. Plants possessed basic nutrients like fats, protein, carbohydrates etc. along with phytochemical residents of the plants which are imperative medicinally and these are accountable for growing and change 
of living being. Plants are used both as raw and in liquid mixtures form for treatment of diseases locally without perceiving their nutritional composition which is important for the proper physiological functioning of the human body $[2,3]$. Plants either used as vegetables or as medicines, nutritional and proximate assessment paly important role in their activities which they exert in-vivo or invitro [4]. According to World health organization, $80 \%$ of the world's population is reliant on plant products for their livelihood. Pakistan possess a large number of medicinal plants which are used locally in curing various diseases. Due to the presence of biologically active ingredients in these medicinal plants, plants are not only used as anticancerous agent, as antimicrobial agents, anti-inflammatory etc but they also used as to provide nutrients to human health. Therapeutic and nourishing excellence of the plants can be obtained by proximate and nutritional assessment. The ash content is imperative due to the mineral present in the plant which may be responsible for any therapeutic result [5]. The superiority and magnitude of proteins in the plant parts has essential role in the assortment of plant parts as nutritient value, in classification and plant development and conservation plants [6]. Due to the importance of food components,

used medicinally Cucumis sativus, Portulaca oleracea, Malus baccata, Saxifraga flagillaris, Geranium wallichianum and Monotheca buxifolia were assessed for proximate and nutrients importance. Cucumis sativus is used as fresh in salads, emollient, coolent, Portulaca oleracea is used as potherb, Malus baccata is nutritive, Saxifraga flagillaris is used in hair dandruff, Geranium wallichianum used in eye problems and dysentery and Monotheca buxifolia is used as purgative. Proximate and nutrient analysis of appetizing fruits, vegetables and wild plants play a vital role in measuring their nutritive importance. Numerous medicinal plants are practice as diet laterally with their remedial profits [7]. So assessment of medicinal plants for nutritional values can aid to know the importance of these selected medicinal plants in curing diseases.

\section{Materials and methods}

The proximate analysis (carbohydrates, fats, proteins, moisture and ash) of all plant samples were determined by using AOAC methods [8].

\section{Determination of moisture}

3 gram of dry plant material was taken in a Petri plate and placed in oven at about $105^{\circ} \mathrm{C}$ for 6 hours, cooled in desiccator and moisture content was calculated using the following formula;

\section{Moisture $(\%)=\underline{\text { Weight of fresh sample }- \text { Weight of dry sample }} \times 100$ \\ Weight of sample}

Determination of ash

$1.0 \pm .01 \mathrm{gm}$ of dried plant materials was taken in a weighted crucible and burnt over low flame. The crucible was then placed in

\section{Determination of fat}

$$
\text { Ash }(\%)=(\%) \text { weight of sample after ashing } \times 100
$$

\section{Weight of sample}

Soxhlet extractor was used to get fat content of the sample. $5 \mathrm{gm}$ of plant material were put on paper thimble and run for six hours on heating mantle. The percent crude fat was determined by using formula (AOCS, 2000);

Crude Fat $(\%)=$ Weight of beaker with fat - Weight of empty beaker $\times 100$

Weight of original sample 


\section{Determination of protein}

Plant sample was added to the digestion mixture (copper sulphate: Potassium sulphate: ferrous sulphate: 1:18.5:0.25 (w/w/w) and $20 \mathrm{~mL}$ of concentrated sulphuric acid was added to the flask and boiled for 2 hours. The digest was transferred to the distillation assembly and $10 \mathrm{~mL}$ of $40 \%$ sodium hydroxide solution was added to the digest in the assembly. This process was followed by titration to remove the ammonium borate formed in distillation process. The percent protein was calculated by the following formula;

$$
\text { Protein }(\%)=\underline{1.4 \times 6.25 \times 0.1 \mathrm{~N} \mathrm{HCl} \times \mathrm{Vol} \mathrm{OF} \mathrm{H}_{2} \mathrm{SO}_{4} \text { (used) }}
$$

Weight of sample

\section{Determination of carbohydrates}

Carbohydrate was determined by using the formula;

Carbohydrate $($ in grams $)=100-(\%$ crude fat $+\%$ crude fiber $+\%$ Ash $+\%$ Protein $)$

\section{Results}

Proximate composition of plants provides a valuable information about its medicinal and nutritional quality. The values of moisture, ash, fats, protein and carbohydrate of selected medicinal plants are shown in (Table $1 \&$ Figure 1).

Table 1. Proximate composition of selected medicinal plants (in percentage)

\begin{tabular}{|c|c|c|c|c|c|c|}
\hline S. No. & Plant Name & Ash & Moisture & Protein & Carbohydrate & Fat \\
\hline 1 & Cucumis sativus & 20 & 16.26 & 2.55 & 47.19 & 14 \\
\hline 2 & $\begin{array}{c}\text { Portulaca } \\
\text { oleracae }\end{array}$ & 26.44 & 11.41 & 1.66 & 57.49 & 3 \\
\hline 3 & Malus baccata & 22.83 & 18.69 & 1.75 & 52.73 & 4 \\
\hline 4 & $\begin{array}{c}\text { Saxifraga } \\
\text { flagillaris }\end{array}$ & 9.92 & 15.50 & 4.37 & 62.79 & 7.42 \\
\hline 5 & $\begin{array}{c}\text { Geranium } \\
\text { wallichianum }\end{array}$ & 17.67 & 10.27 & 3.39 & 64.68 & 4.07 \\
\hline 6 & $\begin{array}{c}\text { Monotheca } \\
\text { buxifolia }\end{array}$ & 6.01 & 11.17 & 0.85 & 74.27 & 7.7 \\
\hline
\end{tabular}

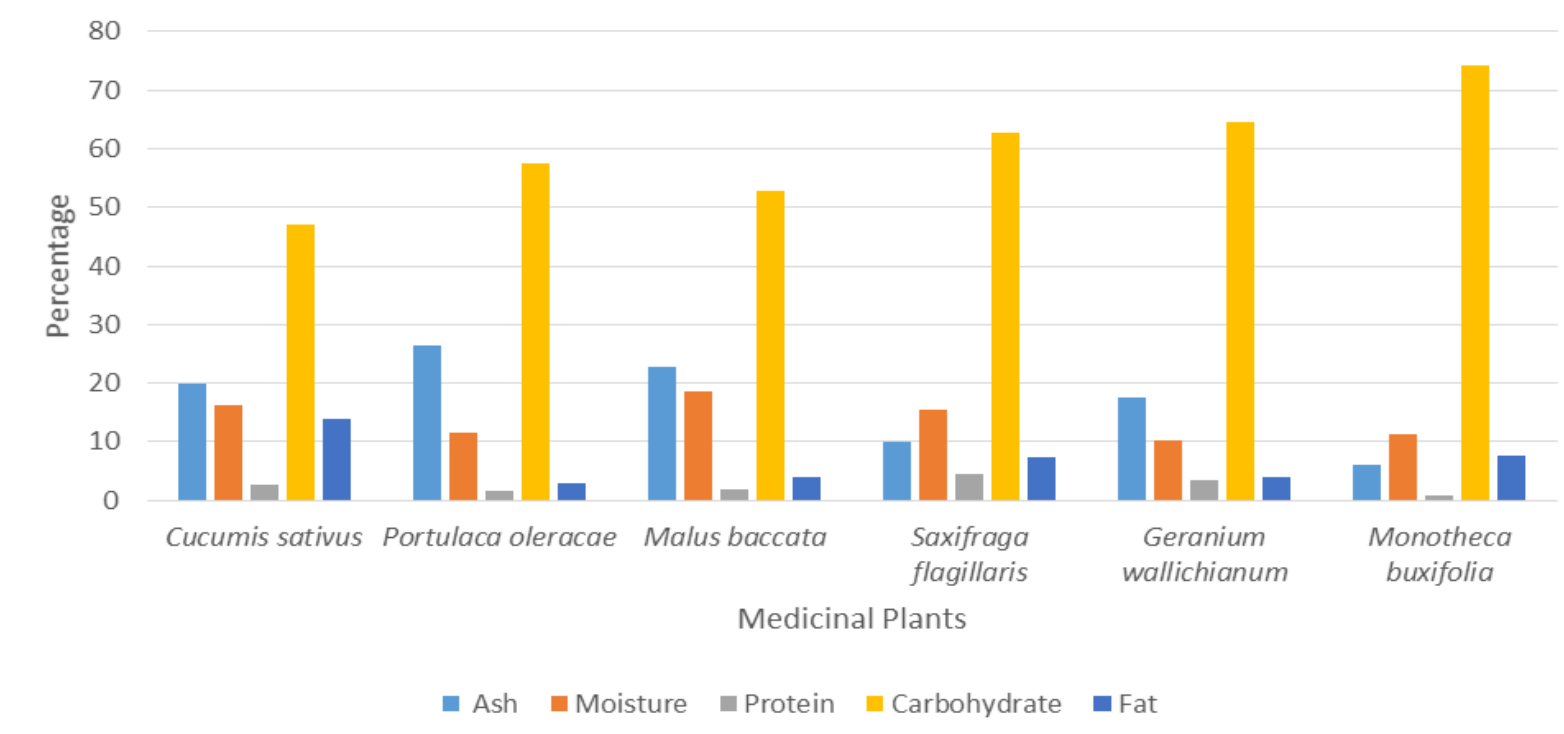

Figure 1. Comparative proximate composition of selected medicinal plants, using AOAC method 


\section{Determination of percentage of ash}

Percentage of ash was determined by with help of furnace by taking temperature up to $600 \mathrm{C}^{\mathrm{o}}$ (Figure. 2). The highest value of percentage of ash was found in Portulaca oleracae seeds and it was 26.44. Malus baccata fruit showed 22.83 and ash percentage in Cucumis sativus seeds was 20. 17.67 percentage was of Geranium wallichianum rhizome and 9.92 and 6.01 was the percentages of Saxifraga flagillaris rhizome and Monotheca buxifolia leaves respectively.

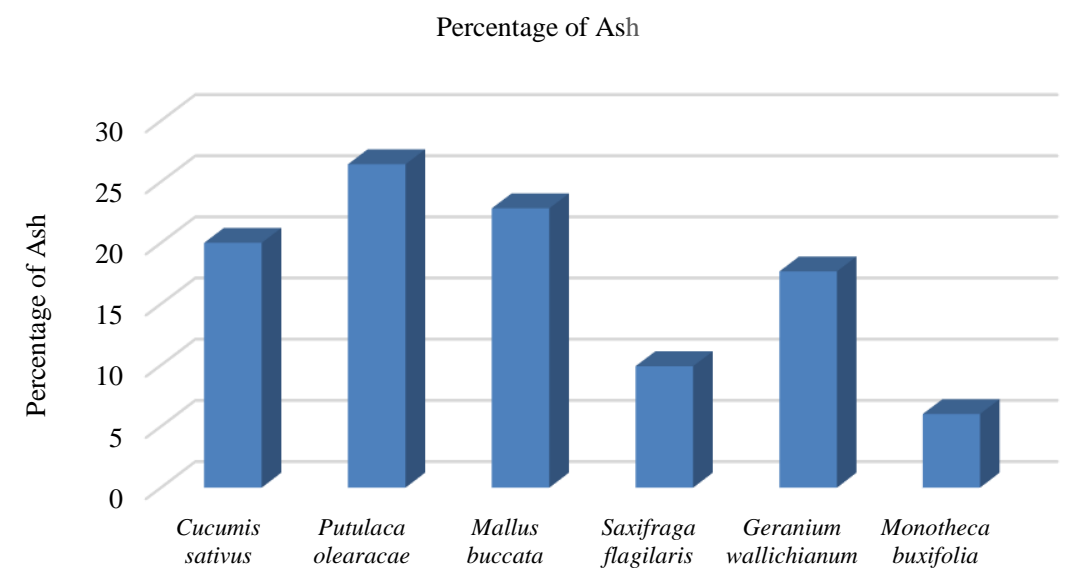

Figure 2. Showed Ash content, the selected medicinal plants showed different percentage of ash content, using AOAC method

\section{Determination of moisture}

The moisture composition of selected medicinal plants were showed in (Figure 3) 18.69 was the highest percentage in Malus baccata fruit which is followed by Cucumis sativus seeds with 16.26 percentage and
Saxifraga flagillaris rhizome showed 15.5 percent of moisture. Portulaca oleracae seeds, Monotheca buxifolia leaves and Geranium wallichianum rhizome showed 11.14, 11.17 and 10.27 percent of moisture respectively.

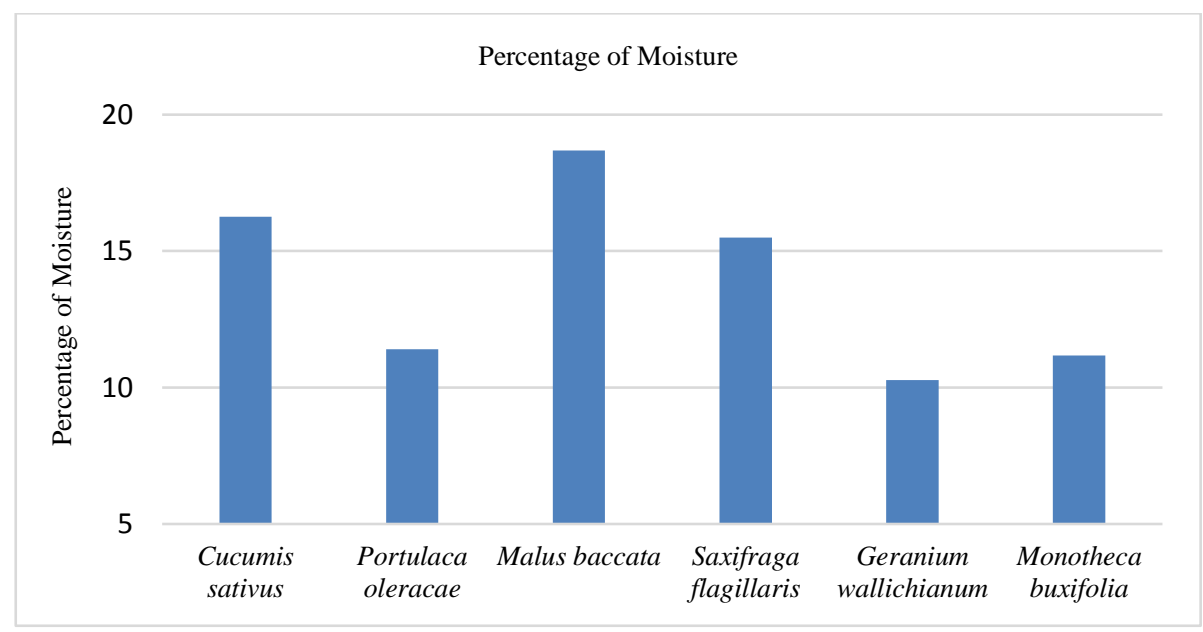

Figure 3. Showed Moisture content of selected medicinal plants, all these selected plants showed various percentage of moisture content, using AOAC method 


\section{Determination of protein}

Protein content was high in Saxifrage flagillaris rhizome with a percentage of 4.37 and Geranium wallichianum rhizome with 3.39 percentage. The remaining plants i. e.
Cucumis sativus seeds showed 2.55, Malus baccata fruit have 1.75, Portulaca oleracae seeds have 1.66 and Monotheca buxifolia leaves possess 0.85 percentages of protein content (Figure 4).

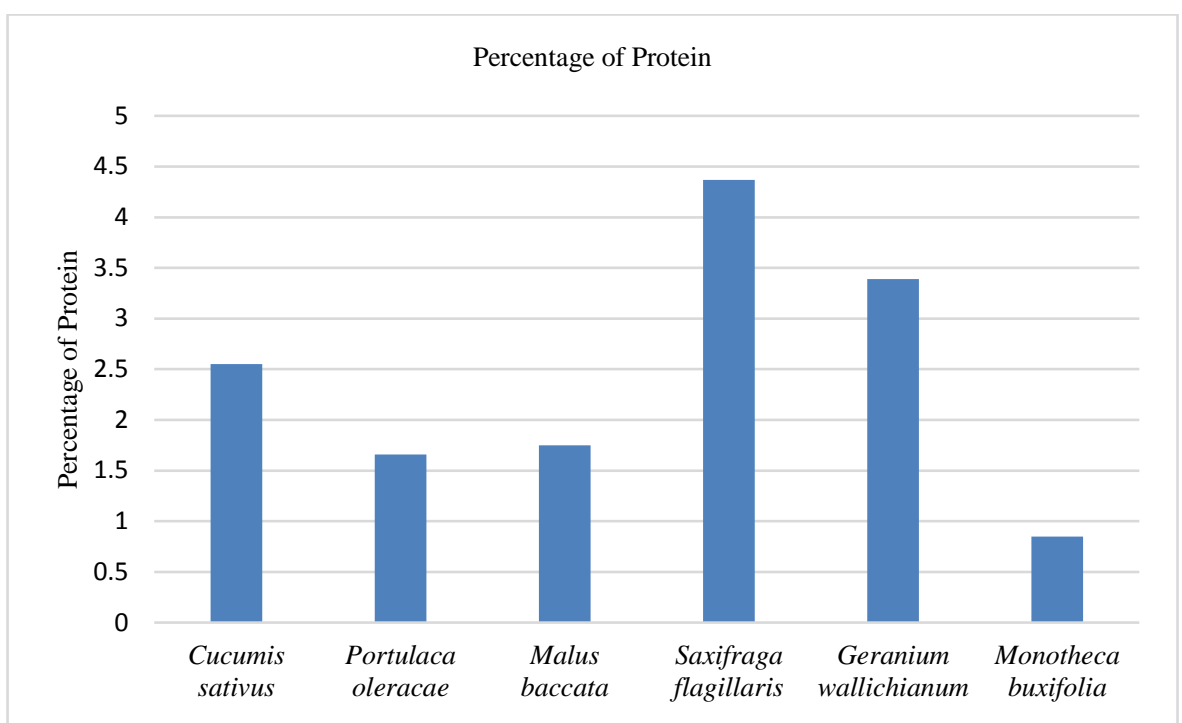

Figure 4. Showed percentage of protein content, Saxifrage flagillaris showed high percentage among the selected medicinal plants, using AOAC method

Determination of carbohydrate

The carbohydrate composition of Monotheca buxifolia leaves was high with a percentage of 74.27. Geranium wallichianum rhizome have $64.68 \%$, Saxifraga flagillaris rhizome have $62.79 \%$, Portulaca oleracae seeds showed $57.49 \%$, Malus baccata fruit have $52.73 \%$ and Cucumis sativus seeds have $47.19 \%$ of carbohydrate content (Figure 5).

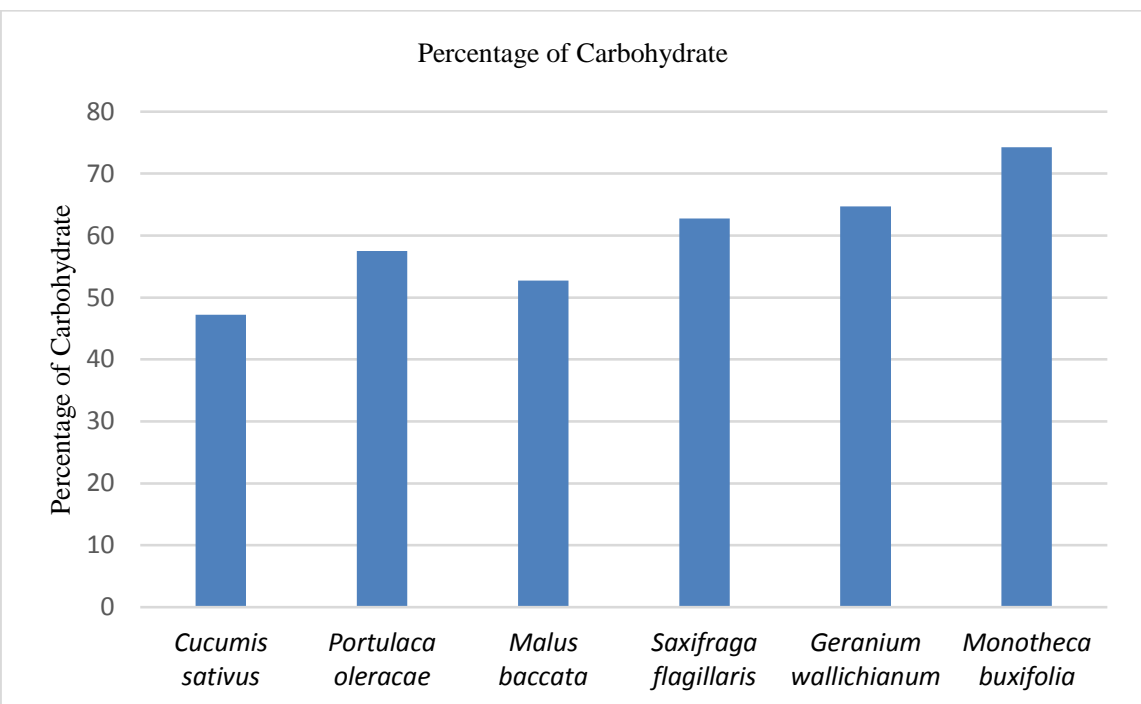

Figure 5. Showed carbohydrate content of these selected medicinal plants, all selected plants possess nearly same percentage of carbohydrate, using AOAC method 


\section{Determination of fat}

The fat content of Cucumis sativus seeds was the highest with a value of $14 \%$. Saxifrage flagillaris rhizome and Monotheca buxifolia leaves showed 7.42 and $7.7 \%$ fat content.
Geranium wallichianum rhizome, Malus baccata fruit and Portulaca oleracae seeds have $4.07,4$ and $3 \%$ fat respectively (Figure $6)$.

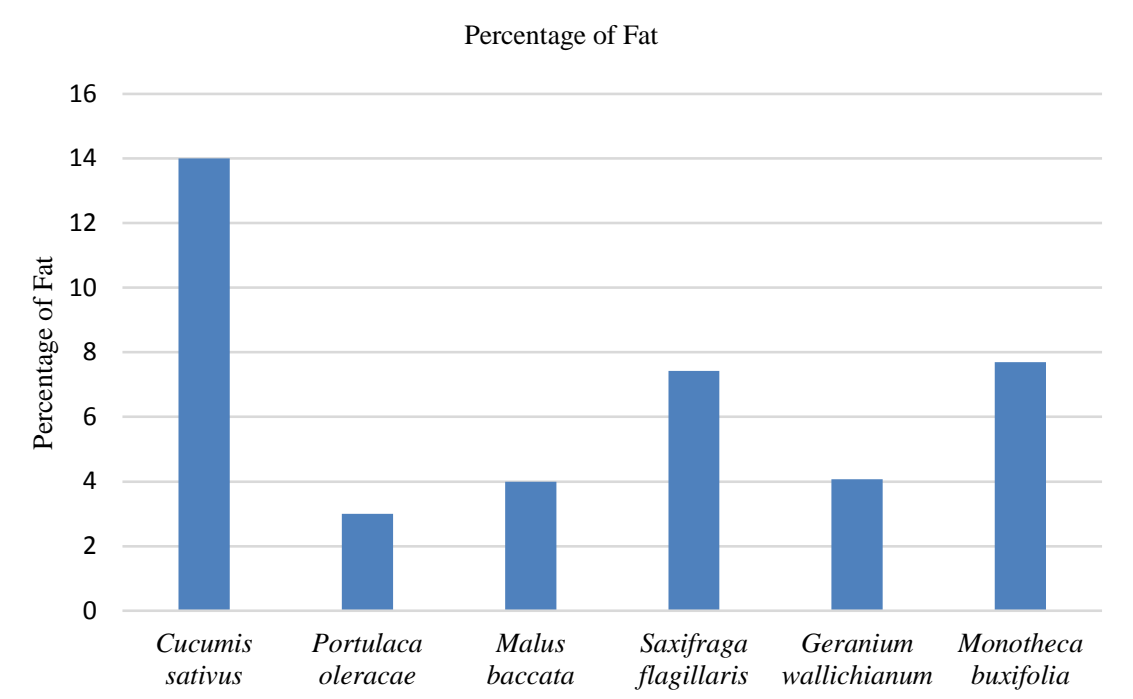

Figure 6. Showed comparison of fat content among the selected medicinal plants, where the Cucumis sativus have high percentage as compared to other selected plants, using AOAC method

\section{Discussion}

The nature has provided abundant plant wealth for all living creatures, which possess medicinal virtues. The important values of some plants have long been published but a large number of them remain unexplored as yet. So there is a necessity to explore their uses and to conduct pharmacognostic and pharmacological studies to ascertain their therapeutic properties [9]. The basic nutritional importance of plants is assessed by their content of protein, carbohydrate, fats and oils, minerals, vitamins and water which are responsible for the growth and development in man and animals $[10,11]$. Carbohydrates, fats and protein are the essential nutrients of life. The quality and quantity of proteins in the seeds are basic factors and important for the selection of plants for nutritive value, systematic classification and plant improvement programs [12]. The proximate analysis of Aleo vera where carbohydrates have the same high percentage like our results followed by fats and protein [13]. Many medicinal plants like Urginea altissima possess low ash percentage (6.66\%) [14].The ash content also revealed comparable results with the previously analyzed medicinal plants, Ammonum sulbulatum (6.97\%) and Rhazya stricta $(6.21 \%)[15,16]$. The highest percentage of ash was found in Portulaca olearacae seeds and was 26.44. Malus baccata fruit showed 22.83 and ash percentage in Cucumis sativus seeds was 20. Geranium wallichianum rhizome showed 17. 67 percent of ash and 9.92 and 6.01 was the percentages of Saxifraga flagillaris rhizome and Monotheca buxifolia leaves respectively. Some workers reported that ash content progressively decline towards maturity in some plants [16]. The ash content in $A$. aspera, growing in the African region ranged between 8 to 14\% [17]. This is in conformity to our results suggesting that different environmental conditions can drastically 
impact the essential plant constituents. The ash content is a reflection of the mineral contents preserved in that plant [10]. Portulaca oleracae with high percentage of ash, contain high amount of minerals as compared to the rest of plants analyzed in the present study.

It is reported that moisture content varied in different species which is dependent on the physiology and environment of the plant. Moisture content depends on the environmental conditions such as humidity, temperature, harvest time, and climate as well as storage conditions. Thus it is important for food scientists to be able to reliably measure moisture contents $[3,16]$. The moisture content of some medicinal ranged from 0.334 percent for $X$. strumarium to 8.18 percent for $A$. cruentus which is low as compared to the present studies. The present study showed 18.69 was the highest percentage of moisture in Malus baccata fruit which is followed by Cucumis sativus seeds with 16.26 percentage and Saxifraga flagillaris rhizome showed 15.5 percent of moisture. Portulaca oleracae seeds, Monotheca buxifolia leaves and Geranium wallichianum rhizome showed 11.14, 11.17 and 10.27 percent of moisture respectively. Similar work was done by numerous researchers $[18,19]$ who showed that leafy vegetables had higher moisture content as compared to non-leafy or green stock and therefore this is in parallel with the present findings. Our findings are strengthen by reporting high moisture content in Bupleurm falcatum, Otostegia limbata and Valeriana officinalis [2].

Using Kjeldahl method protein was determined. Protein content of ginger was reported 6.4 percent by Hussain et al. [20] which was near to the present finding. In present study protein content was high in Saxifrage flagillaris rhizome with a percentage of 4.37 and Geranium wallichianum rhizome with 3.39 percentage.
The remaining plants Cucumis sativus seeds have 2.55, Malus baccata fruit 1.75, Portulaca oleracae seeds 1.66 and Monotheca buxifolia leaves showed 0.85 of protein content. The present study showed low percentage of protein which is quite low in all these selected plants when compared to work done by Akpabio \& Ikpe [4] they reported crude protein $17.05 \%$ in selected wild plants and this only because of the different parts of the plant used in experimental work. Protein obtained in Urginea altissima was about 3.70\% [14]. The crude protein content was different in different plants growing at different parts or locations. Like the plants growing in Nigeria and Swaziland had significantly different contents of crude protein content. Medicinal plants like Momordica foecide leaves and balsam apple contained 4.6 and 11.29 percent of crude proteins respectively [21]. These findings support our study. Protein content about was 1.052 percent for A. lebbeck, 0.88 percent for $A$. aspera, 0.82 percent for $A$. cruentus, 0.64 percent for $X$. strumarium, and 0.4761 percent for $C$. procera [22]. These findings vary from the result obtained in our findings as they have low content of protein as compared to the present study. The results also vary from some other workers and this variation might be due to variation in environments, plant parts used and ability of the plant physiology $[2,18,19]$.

Carbohydrates have vital roles in living organisms. They can easily be oxidized to yield instant energy, their polymers act as energy storage molecules and their derivatives are found in a number of biological molecules including coenzymes and the nucleic acids [23]. The carbohydrate composition of Monotheca buxifolia leaves was high with a percentage of 74.27. Geranium wallichianum rhizome have 64.68 percent, Saxifraga flagillaris rhizome have 62.79 percent, Portulaca oleracae seeds showed 57.49 percent, Malus baccata fruit 
have 52.73 percent and Cucumis sativus seeds have 47.19 percent of carbohydrate content. The carbohydrate percentage is high when compared present work with past research done by some workers like Akpabio \& Ikpe [4] where carbohydrate was 46.02 percent. This difference may be due to the part of the plants used. Some workers got 81.7 percent of carbohydrates in .Urginea altissima [14]. The present study reported carbohydrates value which is high and this in comparison with the previous results, where carbohydrate content of leaves of Bambusa vulgaris, Euphorbia hirta, Lawsonia inarmic, Mimosa pudica, Bidens pilosa, Croton zambesicus and Persia americanas were analyzed and all the plants had high carbohydrate content [24], these result justify our present work. Many researchers reported that carbohydrate content is high in Fagonia cretica, Peganum harmala, Tribulus terrestris, Chrozophora tinctoria and Ricinus communis [25], these also justify the present findings.

The fat content of Cucumis sativus seeds was the highest with a value of 14 percent in the present endeavor. Monotheca buxifolia leaves and Saxifrage flagillaris rhizome showed $7.7 \%$ and 7.42 percent of fat content respectively. Geranium wallichianum rhizome, Malus baccata fruit and Portulaca oleracae seeds have 4.07, 4 and 3 percent of fat content respectively. These findings are an agreement with the previous works $[2,16$, $18,19,24,25]$. Wild plants are potent sources of nutrition and their associated contents can be used for as conventional food and vegetables and for curing illnesses [26-28].

\section{Conclusion}

It is concluded from the present research that medicinal plants are not only sources for the cure of diseases but also these medicinal plants can play important role for the maintenance of healthy life and normal body functioning by providing energy full nutrients for growth and development in the hidden form in medicinal plants. In the light of above results medicinal plants used from time immemorial are best sources of food and remedial agents, imperative for biological, pharmacological activities leading to biochemical isolation for treatment of diseases.

\section{Author's contributions}

Experiment designed by: HA Begum, M Hamayun \& N Shad, Performed the experiments: HA Begum \& $\mathrm{N}$ Shad, Analyzed the data: HA Begum, N Shad, T Yaseen \& F Asad, Lab Facility provided by: HA Begum \& N Shad, Wrote the paper: HA Begum.

\section{References}

1. Sen T \& Samanta SK (2014). Medicinal plants, human health and biodiversity: a broad review. Biotechnological Applications of Biodiversity, Springer, Berlin, Heidelberg pp 59-110.

2. Adnan M, Hussain J, Shah MT, Shinwari ZK, Ullah F, Bahader A \& Watanabe T (2010). Proximate and nutrient composition of medicinal plants of humid and sub-humid regions in Northwest Pakistan. $J$ of Medicinal Plants Res 4(4): 339-345.

3. Hussain J, Rehman NU, Khan AL, Ali L, Al-Harrasi A, Shinwari ZK \& Rizvi TS (2013). Proximate Based Comparative Assessment of Five Medicinal Plants to Meet the Challenges of Malnutrition. European J of Medicinal Plants 3(3): 444-453.

4. Akpabio UD \& Ikpe EE (2013). Proximate composition and nutrient analysis of Aneilema aequinoctiale leaves. Asian J Plant Sci Res 3(2): 5561.

5. Tomescu A, Rus C, Pop G, Alexa E, Radulov I, Imbrea IM \& Negrea M (2015). Researches regarding proximate and selected elements composition of some medicinal plants belonging to the lamiaceae family. Agronomy Series of 
Scientific Research/Lucrari Stiintifice Seria Agronomie, 58(2).

6. Hussain J, Khan FU, Ullah R, Muhammad Z, Rehman N, Shinwari ZK \& Hussain SM (2011). Nutrient evaluation and elemental analysis of four selected medicinal plants of Khyber Pakhtunkhwa, Pakistan. Pak J Bot 43(1): 427-434.

7. Pandey M, Abidi AB, Singh S, \& Singh RP (2006). Nutritional evaluation of leafy vegetable paratha. $J$ of Human Ecology 19(2): 155-156.

8. AOCS, (Americn Oil Chemist Socity) 2000. $5^{\text {th }}$ edition section BC. 2-24, BC4-91.

9. Ahmad M, Qureshi R, Arshad M, Khan MA, \& Zafar M (2009). Traditional herbal remedies used for the treatment of diabetes from district Attock (Pakistan). Pak J Bot 41(6): 2777-2782.

10. Akinniyi JA \& Waziri M (2011). Proximate Value and Mineral Content of the Shoot of Borassus Aethiopummart (GIGINYA). J of Chemical Society of Nigeria 36(1): 10-14.

11. Waziri M \& Saleh IA (2015). Proximate analysis and phytochemical screening of Psidium guajava (Guava) and Cucumis sativus (Cucumber) grown in Gashua Fadama area of Yobe state, Nigeria. Inter Res $J$ of Pure and Appl Chem 6(2): 77.

12. Nisar M, Tariq SA \& Ihsanullah (2009). Nutritional levels of Indigofera gerardiana wall and crataegus songrica K Koch. Pak J of Bot 41(3): 1359-1361.

13. Haque $M Z$, Islam MB, Jalil MA \& Shafique MZ (2014). Proximate Analysis of Aloe vara Leaves. IOSR J of Appl Chem 7(6): 36-40.

14. Kamba AS, Abubakar L, Muhammad MU, Adamu SM \& Muhammad S (2013). Proximate composition and levels of some anti-nutrient contents of
Urginea altissima. J of Phys Sci Innova 5(1): 241-247.

15. Hussain J, Khan A, Rehman N, Zainullah KF, Hussain ST \& Shinwari ZK (2009). Proximate and nutrient investigations of selected medicinal plants species of Pakistan. Pak J Nut 8: 620-624.

16. Hussain J, Ullah R, Rehman N, Khan AL, Muhammad Z, Hussain, FUKST \& Anwar S (2010). Endogenous transitional metal and proximate analysis of selected medicinal plants from Pakistan. .J Med Plants Res 4(3): 267270.

17. Dougall HW \& Bogdan AV (1958). Browse plants of Kenya - with special reference to those occurring in South Baringo. E Afr Agric For J 23(4): 236245.

18. Das P, Devi LP \& Gogoi M (2009). Nutrient composition of some regional recipes of Assam, India. Studies on Ethno-Med 3: 111-117.

19. Hanif R, Iqbal Z, Iqbal M, Hanif S \& Rasheed M (2006). Use of vegetables as nutritional role in human health. $J$ Agric Biol Sci 1: 18-22.

20. Hussain J, Khan AL, Rehman N, Hamayun M, Shinwari ZK, Ullah W \& Lee IJ (2009). Assessment of herbal products and their composite medicinal plants through proximate and micronutrients analysis. $J$ of Medicinal Plants Res 3(12): 1072-1077.

21. Hassan LG \& Umar KJ (2006). Nutritional value of Balsam Apple (Momordica balsamina L.) leaves. Pak J Nutr 5(6): 522-529.

22. Hussain J, Rehman NU, Khan AL, Hamayun M, Hussain SM \& Shinwari ZK (2010). Proximate and essential nutrients evaluation of selected vegetable species from Kohat region. Pakistan. Pak J Bot 42: 1137-1154. 
23. Hasan HH, Habib IH, Gonaid MH \& Islam M (2011). Comparative phytochemical and antimicrobial investigation of some plants growing in Al Jabal Al-Akhdar. J Nat Prod Plant Resour 1(1): 15-23.

24. Abidemi OO (2013). Proximate Composition and Vitamin Levels of Seven Medicinal Plants. Interna. $J$ of Enginee Sci Inven 2(5): 47-50.

25. Ghulam D, Farrukh H \& Fatima K (2013). Proximate analysis of plants of family Zygophyllaceae and Euphorbiaceae during winter. Sarhad $J$ of Agri 29(3): 395-400.
26. Shad AA, Shah HU \& Bakht J (2013). Ethnobotanical Assessment and Nutritive Potential of Wild Food Plants. The J of Animal \& Plant Sci 23(1): 2013, P: 92-97.

27. Hussain T (2000). Food composition table for Pakistan. Department of Hum Nutr and Agri Chem NWFP. Agri Uni Peshawar.

28. Hussain J, Khan FU, Ullah R, Muhammad Z, Rehman NU, Shinwari ZK, Khan IU, Zohaib M, Din I \& Hussain SM (2011). Nutrient evaluation and elemental analysis. Pak J Bot 43(1): 427-434. 